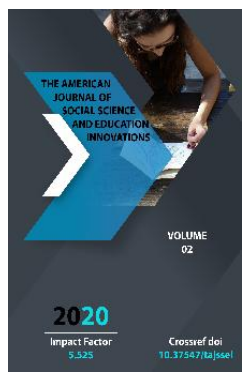

\title{
Issues Of Improving The Institution Of Placing Children Deprived Of Parental Care In Uzbekistan
}

\author{
Dinara Babajanova \\ PhD in law, Tashkent state university of law, Uzbekistan
}

Journal Website:

http://usajournalshub.c

om/index,php/tajssei

Copyright: Original

content from this work

may be used under the

terms of the creative

commons attributes

4.0 licence.

\section{ABSTRACT}

This article discusses the issues of adoption, foster care and the appointment of guardians and trustees, as well as issues related to the upbringing of children deprived of parental care, innovations in family law and the placement of children deprived of parental care.

\section{KEYWORDS}

Adoption, guardian and trustee, Family Code of the Republic of Uzbekistan, children deprived of parental care, houses "Mercy", family institute.

\section{INTRODUCTION}

Latterly, the issue of adoption, family education and the appointment of guardians and trustees has caused a lot of discussion in the scientific community. In modern conditions, support for families and children as an important direction of state social policy is in the constant focus of the state and society. After all, it is the state and society that are interested in the development of the next generation. President of the Republic of Uzbekistan Shavkat Mirziyoyev in his Address to the Oliy Majlis: "Dear children, we set great tasks for the happiness and improvement of our grandchildren, for the bright future of our people," he said [1].

In the modern world, this is an important part of society - the family is undergoing significant changes. This issue becomes even more complicated when it comes to parenting. Thus, Article 150 of the Family Code of the Republic of Uzbekistan provides for the placement of children deprived of parental 
care (adoption, patronage) and institutional forms (educational institutions, medical institutions, social protection institutions and other similar institutions).

Article 64 of the Constitution of the Republic of Uzbekistan states that the state and society provide care, upbringing and education for orphans and children deprived of parental care, and also encourage charitable activities dedicated to children.

Article 20 of the Convention on the Rights of the Child states that a child who is temporarily or permanently deprived of his family environment or cannot remain in such an environment due to the interests of the child has the right to special protection and assistance[2].

\section{MATERIAL AND METHODS}

Although adoption is one of the priority forms of raising children deprived of parental care, its legal framework requires further improvement. Relationships in this regard are regulated by the Family Code, the Civil Procedure Code and by-laws, then their compliance with modern requirements requires a comprehensive analysis of their compliance with the requirements of today's reforms.

Article 154 of the Family Code states that citizens of the Republic of Uzbekistan have the preferential right of adoption. The legislature's approach in this regard is clear.

As a result of innovations in family law, the adoption procedure was introduced. At the same time, adoption cases were included in the category of cases considered separately. Contemporaneously, the adoption process was approved by Chapter 20 of the Family Code, Chapter 29 of the Civil Procedure Code and it is regulated by the Regulation on the adoption and upbringing (patronage) of minors, approved by the Resolution of the
Cabinet of Ministers of the Republic of Uzbekistan dated April 12, 1999 No. 171 "On the approval of normative documents necessary for the implementation of the Family Code of the Republic of Uzbekistan." It should be noted that although timely adoption and family upbringing played an important role, today it is outdated in content and spirituality. The regulation consists of two sections, the first of which is devoted to the adoption of minors and consists of 32 paragraphs, and the second section is devoted to family education (patronage) and consists of 20 paragraphs. In the first section of this law, you may find a number of ambiguities and outdated norms.

In particular, Chapter IV of the first section is entitled "Preparing Adoption Recommendations to the Governor". This chapter shows that the methodological support and organization of educational institutions of the district, city on the basis of documents submitted by district (city) departments, taking into account the health status of the adoptive parent, consent of the adoptive parents, consent of the adoptive parent, family and other conditions prepares a recommendation to the governor of the district, city. However, the administrative procedure for adoption was abolished, and applications for adoption were included in the list of cases considered separately and considered by civil courts in the manner prescribed by the legislation on civil procedure. In this case, only persons under the age of 18 are obliged to submit to the court an opinion that the adoption is justified and meets the interests of the adopted child, given that guardianship and guardianship responsibilities are entrusted to the departments of methodological support and organization of public education.

Another problem in the family legal regulation of adoption is international adoption. There is 
a foreign element in international adoption, and the adopted and adopted have citizenship of different countries or the adoption is carried out on the territory of a foreign state[3].

Furthermore, the complexity of the legal regulation of these relations lies in the fact that the participants in family relations complicated by a foreign element are citizens of several states at the same time. First, the question of which state laws to apply to each intercountry adoption will be a cross-cutting issue. It is also important to take into account the legal system of different countries, the delineation of sources of legal regulation[4]. In our opinion, it is necessary to strengthen the legal mechanism of adoption with the participation of a foreign element in family law. Also, in bilateral agreements of the Republic of Uzbekistan, it is advisable to register adopted children in consular offices, to provide for liability in case of failure to fulfill these obligations.

The negative educational and sociopsychological environment in the "Mercy" homes can be called a problem when placing children left without parental care. In these institutions, children of different ages, born in different social strata, often from a dysfunctional family environment and in a negative social environment, interact with each other and share their "experience".

It is noted that the process of socialization of children, which is a priority in different countries, is changing today. World experience shows that the most optimal way of accommodating children is their adoption. It is the family that takes into account the individual characteristics of the child, as well as the effective implementation of the processes of social education. According to the Czech researcher D. Zavrhek, "in boarding schools they do not teach how to live, they only teach how to live in boarding schools"[5].
This is why the president decided to deinstitutionalize "The houses of mercy". This means the removal of children from the "Mercy" homes and their transfer to a family form of education. The result is an improved environment for raising children who, for some reason, cannot be raised in a family.

Deinstitutionalization of "orphanages" means choosing other forms of family education for low-income children's camps. Noninstitutionalization - Deinstitutionalization is an international term for the expulsion of children from various institutions, the creation of conditions for their life and education outside of boarding schools. Moreover, most children are brought up in a family. Therefore, the development of alternative forms of family education is an important direction, but, of course, not the only one. Because the choice of a one-sided direction does not effectively solve the problem of "social orphanhood".

UNICEF defines lack of institutionalization as "a planning process for the downsizing and / or closure of boarding schools, governed by laws and performance standards, and the creation of various childcare services".

S.E. Drozdovskiy uses the term "noninstitutionalization" to develop services at the local community level, including preventive measures to meet the needs of boarding schools.

Today more than a million children across Europe live in boarding schools. In the past, these institutions were seen as the best way to care for vulnerable children at risk as well as adults with different needs. However, experience shows that specialized agencies perform worse than quality local services. Research in this area shows that short-term institutionalization negatively affects the development of the brains of young children and affects emotional development and behavior throughout life[6]. 
Effective deinstitutionalization requires a systems approach in which the institutional package of community services is just one element of a broader change in societal attitudes towards people with disabilities, including health, rehabilitation, support services, education and employment[7].

The modern realities of European countries show that the traditional concept of a family is becoming more and more narrow in meaning. Most citizens do not want to take on family responsibilities, such as having and raising children, without simply entering into a marriage in the form of a partnership (partnership, common law). However, in some areas, especially in some conservative families, the traditional family essence has been preserved[8]. This situation is due to "the presence of financial difficulties and the fact that children are further complicating these material issues by promoting a lifestyle without commitment". This, of course, further complicates the decision on the placement of children deprived of parental care.

The institution of the family requires the improvement of the legal mechanism for the upbringing of children deprived of parental care in modern conditions of development. In this regard, V.N. Oslon expressed his opinion on the need to develop and introduce new technologies of psychological assistance to children who remain in the institutional education system. Also, unlike children in orphanages, children of other forms of family education will have a clear idea of the future[9].

An analysis of international documents in this regard shows that a policy of noninstitutionalization is being pursued in the broadest sense, namely: 1) a sharp reduction in the number of children in boarding schools; 2) development of a family form of placement of children deprived of parental care; 3) reprofiling of orphanages, including the transfer to auxiliary services; 4) creation of conditions for living, teaching and upbringing of children that cannot be transferred to a family for upbringing.

\section{CONCLUSION}

In conclusion, it should be noted that today family legislation regulating the placement of children deprived of parental care requires further development. The practice of applying family law shows that the system of selection and supervision of foster and guardian candidates, foster parents and foster parents of foster parents in foster families requires improvement of the system. In this regard, problems arise with the legal means of ensuring the placement of children in a family, including the lack of a clear legal mechanism for the implementation of the rights and obligations of the guardianship and guardianship authorities, foster parents, foster parents at the legislative level.

In our opinion, it is necessary to develop and adopt rules for the selection and support of foster parents and candidates for guardianship, foster parents and foster parents of foster children in foster care. These rules should provide for the following:

fundamental rules;

the procedure for selecting candidates for upbringing and guardianship, foster parents and foster parents of foster families;

documents required for filing an application for participation in the competition;

functional duties and responsibilities of the guardianship and guardianship authority;

responsibilities of candidates for fostering and guardianship, foster parents and foster parents of family orphanages;

final rules.

The adoption of these rules will determine the rights and obligations of candidates in the selection and supervision of foster parents, 
foster parents and foster parents of foster parents, as well as to achieve transparency of these processes and, as a result, parental care. serves to ensure the rights and legitimate interests of disadvantaged children.

\section{REFERENCES}

1. Message from the President of the Republic of Uzbekistan Shavkat Mirziyoyev to the Oliy Majlis // People's speech. December 28, 2018.

2. Resolution of the Supreme Council of the Republic of Uzbekistan "On joining the Convention on the Rights of the Child" // Bulletin of the Supreme Council of the Republic of Uzbekistan, 1993, article 41.

3. Цветкова О.А. Запрет на осуществление посреднической деятельности при международном усыновлении // Право и образование. 2008. - № 3. - С. 68-71.

4. Содылева О.С. Международное законодательство об усыновлении и правовом положении ребенка на территории Российской Федерации // Право и государство: теория и практика. 2009. - № 3. - С. 110-114.

5. Завиржек А. Как выжить детям с ограниченными возможностями и детям этнических меньшинств в государственных учреждениях длительного пребывания // Журнал исследований социальной политики. 2004. T.2. №2. 10-С.

6. С.Е. Дроздовский. Деинституализация в Республике Беларусь: подходы и рекомендации - Минск: 2016. 14-с.; http://europa.eu/rapid/pressrelease_MEMO-09-96_en.htm?locale=en

7. World Health Organization (WHO) and World Bank, World Report on Disability (2011), p. 148.

8. Euronews.com / application filing date 05/25/2019.
9. Ослон В. Н. Научное сопровождение практики деинституционализации детей-сирот //Детский дом. 2007. №3. - C. 2-7. 